\title{
Does the urban heat island determine the distribution of Fallopia taxa in cities? - preliminary study from Wrocław (Central Europe)
}

\author{
Justyna Soltysiak \\ Department of Botany and Plant Ecology, Wrocław University of Environmental and Life Sciences, \\ Grunwaldzki sq. 24a, 50-363 Wrocław, Poland \\ e-mail: justyna.soltysiak@upwr.edu.pl \\ Received: 26 August 2019/ Accepted: 2 March 2020
}

\begin{abstract}
Among the invasive plant species found in Europe and North America, particular attention is paid to the Fallopia (Reynoutria) genus: Fallopia japonica, Fallopia sachalinensis and the hybrid created as a result of their crossing - Fallopia $\times$ bohemica. Many works describe the extraordinary expansiveness of knotweeds, in anthropogenic habitats, especially in large cities, the representatives from the Fallopia genus are already a permanent element of the local flora. The specific ecological properties of the cities can favour the expansion of Fallopia genus. The goal of this work was to answering the question - is there a relationship between the spread of knotweeds in the city and the local climatic conditions in the form of the so-called urban heat island? The field work was carried out in Wrocław, which is the fifth largest city in Poland, with an area of $292.82 \mathrm{~km}^{2}$. The study showed that despite the potentially broad thermal amplitude, Fallopia japonica prefers the areas in the city with the highest temperature. The invasion of this species proceeds most intensively in the warmest regions of the city. Similar tendencies are observed in the case of the interspecies hybrid - Fallopia $\times$ bohemica. The third taxon - Fallopia sachalinensis - clearly prefers slightly colder parts of the city. It is worth noting that representatives of the Fallopia genus do not appear in the coldest parts of Wrocław. This is quite puzzling, because in these city areas, there are some types of semi-natural habitats which the invasive knotweeds usually willingly occupy. The preliminary study shown that in the urban ecosystem, the thermal factor influences the spread of the Fallopia genus. Research in this area regarding the all Fallopia taxa will continue.
\end{abstract}

Keywords: Reynoutria spp., knotweeds, invasive plants, UHI, urban areas.

\section{Introduction}

The ecosystems' susceptibility to the expansion of foreign species is determined by their ecological properties. Particularly vulnerable to massive biological invasions are biological ecosystems, which are considered as key points of entry for many non-native species but are also foci for escape foreign plants into surrounding areas (Gaertner et al., 2017). The urban flora in the central part of Europe is characterized by a large number of non-native species. According to Pyšek (1998), the share of foreign species in European cities on average equals $40 \%$, of which $15 \%$ is attributed to archaeophytes - species brought to Europe before the end of the 15 th century, and $25 \%$ to neophytes plants imported and settled in Europe after 1492.

Cities are rich in non-native plant species, what is related to specific attributes of urban areas (Kühn et al, 2017). Human activity is beneficial to the dispersion of alien plants through the creation of new plant migration routes (roads, motorways, tram and railway lines) and the expansion of potential centres for their spread (parks, municipal gardens and allotments). Moreover, many urban ar- 
eas are situated along waterways which provide corridors for dispersal of rapid dissemination of propagules (Säumel \& Kowarik, 2010).

Another important element affecting the state of the local flora are the modifications and disturbances of the environmental conditions (Parepal et al., 2013). Cities are characterized by a greater air dryness than the adjacent areas, in urban environments there are high concentrations of dust and gas pollutants. Urban soils are often saline and contaminated with heavy metals. These factors affect the state of the local flora and facilitate the expansion of invasive species. It was proven that invasive species are more abundant and diverse in cities because of high levels of disturbance and less competition (Gaertner et al., 2017).

An important environmental factor in the cities, which has clearly been modified as a result of human activity, is the temperature. A phenomenon commonly occurring in large agglomerations is the urban heat island (UHI). Its shape is determined by the city development and additional sources of heat emission. The result is the increase of the average annual temperature in the most developed zone and of the minimum winter temperatures in the city, with temperature drops below $0^{\circ} \mathrm{C}$ becoming less frequent (Studnik-Wójcikowska, 2012). The thermal conditions of the city resulting from the UHI influence significantly affect the phenology of plants present there and promote the development of thermophilic species, especially of foreign origin.

The goal of this work was: a) to present a spatial pattern of the distribution of three highly invasive taxa of plants of the Fallopia genus ( F. japonica, F. $\times$ bohemica and $F$. sachalinensis) in the city of Wrocław, considering its specific thermal conditions, and b). answering the question - is there a relationship between the spread of knotweeds in the city and the commonly occurring phenomenon of the urban heat island?

\section{Invasive taxa from the Fallopia genus as an object of the conducted study}

Among the invasive plant species found in Europe and North America, particular attention is paid to the Fallopia genus: Fallopia japonica, Fallopia sachalinensis and the hybrid created as a result of their crossing - Fallopia $\times$ bohemica. All knotweeds are clonal geophytes with substantial sizes of aboveground and underground parts, and their characteristic feature is the immense strength of the vegetative propagation (Fabiszewski \& Brej, 2008). Representatives of the Fallopia genus belong to plants that cause serious environmental and economic problems (Baliey et al., 2008; Tokarska-Guzik et al., 2012). They are aggressive invasive plants the presence of which in the environment undoubtedly threatens the native flora (Fabisze- wski \& Brej, 2008). The literature emphasizes the great ability of knotweeds to compete with local plant species (Bimová et al., 2004). The knotweeds often form tight phytocoenoses, casting a shadow on the ground and preventing the growth of other species (Bailey et al., 2008). In addition, these plants alter the physical and chemical properties of the habitat (Simens \& Blossey, 2007). Removing the thickets of these onerous weeds together with combating them on a regular basis takes even up to several years. Many works describe the extraordinary expansiveness of knotweeds, especially in anthropogenic habitats (Mandák et al., 2004; Chmura et al., 2013; Rahmonov et al., 2014; Sołtysiak \& Brej, 2014). This phenomenon can be observed in Poland, where, mainly in large cities, the representatives from the Fallopia genus are already a permanent element of the local flora (Fojcik \& Tokarska-Guzik, 2000). In cities, knotweeds are dominating the anthropogenic areas: roadside, landfills, rubble, railway embankments, where they inhabit soil with high concentrations of heavy metals (e.g. $\mathrm{Cd}, \mathrm{Cr}, \mathrm{Pb}$ ) and exhibit tolerance to these metals (Berchová-Bimová et al., 2014; Sołtysiak \& Brej, 2019). They also display an ease in inhabiting semi-natural habitats: suburban meadows, riverside areas. They can be encountered in parks and gardens to which they were usually introduced as ornamental plants (Sołtysiak \& Brej, 2014).

Research shows that the above-mentioned specific ecological properties of the cities favour the expansion of Fallopia genus (Sołtysiak \& Brej, 2014). Understanding the nature of the impact of individual ecological factors on the distribution of taxa of the Fallopia genus is important in the context of predicting the invasion of these knotweeds in cities that may become centres of secondary invasion of knotweed on the outskirts of the city.

\section{Characteristics of the study area - location and climatic conditions of the city of Wroclaw}

The field work was carried out in Wrocław (Central Europe $17^{\circ} \mathrm{E}, 52^{\circ} \mathrm{N}$ ). It is the fifth largest city in Poland, with an area of $292.82 \mathrm{~km}^{2}$. The city is in the middle of Lower Silesia, the Silesian Lowland and the Wrocław Plain. The landscape of the city is dominated by the Odra River, which, with its branches, canals, oxbow lakes and backwaters, forms the main ecological axis of the city in the east-west direction (Szymanowski, 2004). Wrocław's climate is characterised by features typical of transitional climate of the temperate zone. The city's location in the Odra valley and in the outskirts of the Sudetes results in its thermal privilege referred to as the "Wrocław-Opole heat area" (Szymanowski 2004). The average annual air temperature in Wrockaw is $9.0^{\circ} \mathrm{C}$. The coldest month is January with the temperature of $-0.4^{\circ} \mathrm{C}$ (monthly average); 
the warmest is July, with the average temperature of 18.8 ${ }^{\circ} \mathrm{C}$ (Dubicki et al., 2002). In the recent years, an increase in the average annual temperature has been observed. The last two decades of the 20th century and the beginning of the 21 st century have been very warm. The frequency of low-temperature days has decreased, especially in the transition seasons (Drzeniecka-Osiadacz et al., 2010). As in other industrial and urban agglomerations, in Wrocław, the local climate conditions are also modified by the phenomenon called the urban heat island (UHI), which manifests itself in increased temperature values in the city (especially in its central parts) in relation to adjacent areas. The basic characteristic of UHI is its intensity, which depends mainly on the size and spatial structure of the city (Szymanowski 2004). The average annual intensity of the urban heat island in the warmest, central area of Wroclaw amounts to $1.0^{\circ} \mathrm{C}$ and alternates from $0.5^{\circ} \mathrm{C}$ in the day to $1.6^{\circ} \mathrm{C}$ during the night. The highest intensity of UHI is recorded during summer nights: from $2.3^{\circ} \mathrm{C}$ in the centre through $1.6^{\circ} \mathrm{C}$ in high buildings to $0.6^{\circ} \mathrm{C}$ in single-family homes. Research shows that the maximal intensity of the urban heat island in Wrocław can reach even up to $9.0^{\circ} \mathrm{C}$ and can appear in the night during any season (Dubicki et al., 2002). The urban heat island in Wrocław has a complicated structure. The warmest city zones (i.e. zones from 6 to 10$)$ cover areas with a concentrated settlement. The highest temperatures are recorded in zones 9 and 10 in the central part of the city. Peripheral districts create their own "heat centres". They experience local temperature drops generated by recreational and park areas. The coldest parts of Wrocław are zones 1 and 2. There consist mainly of irrigation fields, water-bearing areas and agricultural areas (Szymanowski, 2004).

\section{Research methodology}

The study included three taxa of the Fallopia genus: Fallopia japonica var. japonica (Houtt.) Ronse Decraense, Fallopia sachalinensis (F.W.Schmidt ex Maxim.) Nakai. and Fallopia $\times$ bohemica (Chrtek et Chrtková) J.P. Bailey. The search for knotweed in the city began with the designation of basic research fields on the map of Wrocław. For this purpose, the city area was divided into 53 squares with a side of $1 \mathrm{~km}$. Inventory works were carried out in each of the squares; the habitats most frequently occupied by knotweeds were searched in detail. The individual taxa from the Fallopia genus were identified based on the morphological features of the leaves, which were collected from the middle part of the shoots. In individual cases, there were doubts regarding the correct recognition of the interspecies hybrids - Fallopia $\times$ bohemica. These specimens were identified based on an analysis of the number of chromosomes, which are considered as the final deci- sive feature in case of doubt (Bailey et al., 2008). In total, 310 clusters of knotweeds were found in the research area, including 227 of Fallopia japonica, 67 clusters of Fallopia $\times$ bohemica and 16 clusters Fallopia sachalinensis. Their locations have been determined by the receiver of a global positioning system (GPS). Then, these data were plotted on a map illustrating the spatial structure of the urban heat island, thus, obtaining a picture of the spatial distribution of knotweed against the background of thermal conditions of the city (Fig.1). Szymanowski's map (2004) was used here, which shows normalised (0-100) average air temperature distribution from seven selected measurement sessions of UHI occurrence in Wrocław. Distribution of knotweed positions was analysed in the following zones:

1,2 - cold zones, with the lowest temperature $(<11-20)$ and with the lowest intensity of urban heat island in the city

3, 4, 5 - temperate zones (21-50), that is zones encompassing the colder parts of Wrockaw

6, 7, 8 -warm zones, with an elevated temperature (51-80)

9, 10 - the warmest zones, with the highest temperature (81-100) and with the highest intensity of UHI.

Individual zones (1-10) have been designated by Szymanowski (2004) through normalisation of average air temperatures (recorded in the years 2001 and 2002), lower temperature was assigned the 0 value, whereas the highest temperature was assigned the 100 .

\section{Results}

The obtained data allowed analysing the impact of the local climatic conditions - in the form of the so-called urban heat island, on the distribution of knotweed in Wrocław (Fig.1). The number of Fallopia japonica, Fallopia sachalinensis and Fallopia $\times$ bohemica clusters in particular thermal zones of Wrocław were shown in Table 1. The majority of Fallopia japonica and Fallopia $\times$ bohemica clusters were recorded in warm zones, with an elevated temperature (zones from 6 to 8 ) and in the warmest parts of the city (zones 9 and 10).

On the other hand, the third taxon - Fallopia sachalinensis - clearly prefers slightly colder parts of the city. All clusters of this species were found in temperate zones (i.e. in zones 3 and 4). The research shows that in areas of the city with the lowest temperature (zones 1 and 2), representatives of the Fallopia genus are very rare. Three clusters of Fallopia $\times$ bohemica were found in zone 2, in the western part of the city. Two clusters of Fallopia japonica were also found in the same zone in the southern part of the city. It is worth noting that representatives of the Fallopia genus do not appear in in zone 1, which is the coldest part of Wrocław. 


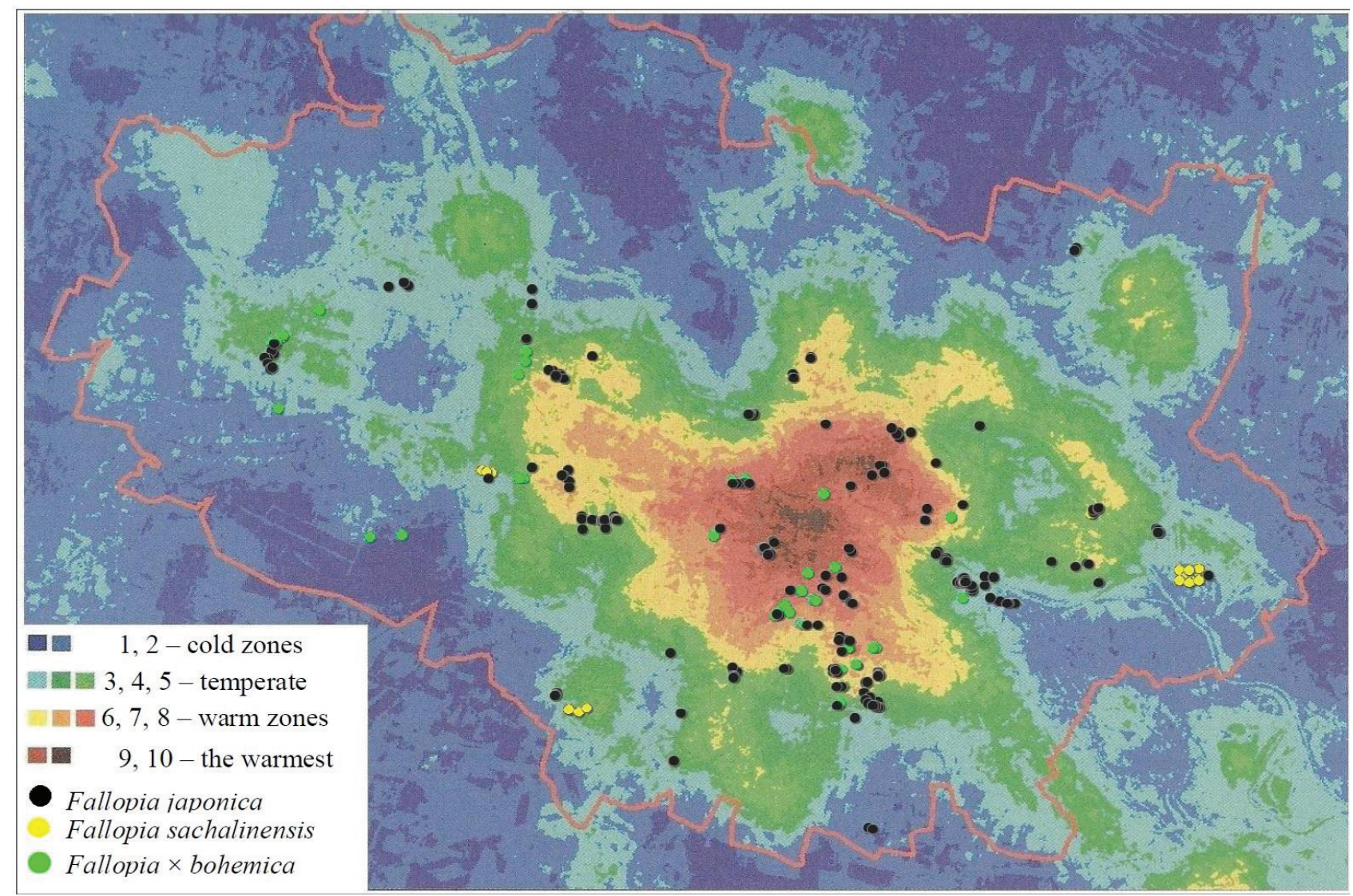

Figure 1. The distribution of three taxa of plants of the Fallopia genus in Wrocław, considering its urban heat island. The map shows normalised [0-100] averaged air temperature from seven measurement sessions of UHI occurrences in Wrocław (Szymanowski, 2004)

Table 1. The number of Fallopia japonica, Fallopia sachalinensis and Fallopia $\times$ bohemica clusters in particular thermal zones of Wrocław

\begin{tabular}{|l|c|c|c|}
\hline \multicolumn{1}{|c|}{ Zones } & F. japonica & F. sachalinensis & F. $\times$ bohemica \\
\hline $\begin{array}{l}\text { cold } \\
(1,2)\end{array}$ & 2 & 0 & 20 \\
\hline $\begin{array}{l}\text { temperate } \\
(3,4,5)\end{array}$ & 78 & 16 & 44 \\
\hline $\begin{array}{l}\text { warm and the warmest } \\
(6,7,8,9,10)\end{array}$ & 147 & 0 & 67 \\
\hline total number of clusters & 227 & 16 & 6 \\
\hline
\end{tabular}




\section{Discussion}

The temperature distribution determines the occurrence of plants on Earth. In addition, plant species numbers (in general) increase with the increasing temperature (Francis \& Currie, 2003; Nobis et al., 2009). The temperature in the city is one of the most important ecological factor; it significantly affects the species composition and the distribution of the local flora. In cities, there are significant differences in temperature between the central and builtup areas and the peripheral areas. In the city centre, where the temperatures are higher, the share of species of foreign origin in the flora increases compared to the adjacent areas (Studnik-Wójcikowska, 2012). The research shows that the phenomenon of the urban heat island, which is common for urban ecosystems, promotes the spread of foreign species in the city centre, especially of neophytes (Kowarik, 1995a), most of which are species originating from warmer climatic zones (Studnik-Wójcikowska, 2012).

Representatives of the Fallopia genus occur in different climatic zones from cold through temperate to desert (Sołtysiak \& Brej, 2012). The Fallopia japonica has the widest geographical range. It occurs in many regions of the European continent, in the north, reaching the Baltic countries and Scandinavia, and in the east, reaching Russia and Ukraine. It is also growing in North America - in Canada and the USA (from Alaska to Georgia), Australia and New Zealand (Tokarska-Guzik et al., 2015). This species has a wide thermal amplitude and can tolerate even low temperatures. For example, rhizomes of Fallopia japonica can survive temperatures of up to $-42^{\circ} \mathrm{C}$ (Beerling, 1993). Yamaguchi et al. (2000) also confirm the high viability and survival ability of Fallopia japonica seedlings in extreme mountain climate conditions.

Research from city of Wrocław showed that despite the potentially broad thermal amplitude, Fallopia japonica prefers the areas in the city with the highest temperature. The invasion of this species proceeds most intensively in the warmest regions of the city. Similar tendencies are observed in the case of the interspecies hybrid - Fallopia $\times$ bohemica, which most often inhabits the warmest areas of the city. The geographical range of this hybrid corresponds to the distribution of the Fallopia japonica. In terms of habitat preferences, this taxon does not differ significantly from its parental species. It is also known that Fallopia $\times$ bohemica is characterized by a high tolerance regarding the type of soil, its salinity (Richards et al., 2008) or the presence of impurities in the environment, e.g. heavy metals (Sołtysiak \& Brej, 2019). There are no studies on the thermal requirements of this hybrid.

The third taxa - Fallopia sachalinensis in comparison to the other ones has a narrower range of occurrence. It also seems that Fallopia sachalinensis has a lower eco- logical tolerance. Research has shown that in Wrocław's urban conditions, this taxon occurs in temperate regions. In the zones where the presence of $F$. sachalinensis has been recorded, the average temperatures range from 5.6 to $8.5^{\circ} \mathrm{C}$ (in spring). In its homeland, the Fallopia sachalinensis grows in areas where the average annual temperature is $4-8^{\circ} \mathrm{C}$ (CABI, 2015), which may partially explain the habitat preferences of Fallopia sachalinensis in the city.

It is worth noting that representatives of the Fallopia genus do not appear in the coldest parts of Wrocław. This is quite puzzling, because in these city areas, there are types of semi-natural habitats (shrubs, banks of river and other bodies of water), which the invasive knotweeds usually willingly occupy (Tokarska-Guzik et al., 2015).

Interpreting the results of the study, it can be concluded that in the urban ecosystem, the thermal factor influences the spread of the Fallopia genus. The research carried out by Groeneveld et al. (2014) also testifies to the significant impact of the urban heat island phenomenon on the ecological properties of knotweeds. The authors analysed, among others, the knotweed's ability to produce seeds in urban conditions. According to them, the urban heat island, which delays the appearance of the first frosts in the warmest areas of the city, significantly affects the phenology of the Fallopia taxa and enables these plants to produce a large number of fully mature seeds. The prolonged frost-free period also affects the Fallopia japonica germination rate, which is higher in large urban centres compared to small towns.

Despite many studies on the invasive taxa from the Fallopia genus, the state of knowledge about the relationship between the temperature and the ecological properties of these onerous weeds is still insufficient. This preliminary research suggests that urban areas with elevated temperatures are more vulnerable to the invasion of knotweeds than the peripheral areas. Elevated temperatures in the city are favourable for the invasion of knotweeds, especially Fallopia japonica and Fallopia $\times$ bohemica the largest number of these taxa were recorded in the warmest areas of the city. This is important in the context of forecasting future threats related to the presence of invasive plants in cities and in the context of the climate change (global warming), which is favourable for the invasion of foreign species. Quite few examples are known where the successful invasion of plants can be due to an interaction of directional climatic changes (rising temperatures since 1850) (Kowarik, 1995b). Cities are excellent research centres, where it is possible to observe the impact of temperature changes in the form of the urban heat island on the foreign invasive plants. Research in this area regarding the Fallopia taxa will continue. 


\section{References}

Bailey J.P., Bimová K. \& Mandák B., 2008, Asexual spread versus sexual reproduction and evolution in Japanese Knotweed s.l. sets the stage of "Battle of the Clones". Biological Invasions 11: 1189-1203.

Beerling D.J., 1993, The impact of temperature on the northern distribution limits of the introduced species Fallopia japonica and Impatiens glandulifera in NorthWest Europe. Journal of Biogeography 20: 45-53.

Berchová-Bímová K., Sołtysiak J. \& Vach M., 2014, Role of different taxa and cytotypes in heavy metals absorption in knotweeds (Fallopia). Scientia Agriculturae Bohemica 45: 11-18.

Bímová K., Mandák B. \& Kasparova I., 2004, How does Reynoutria invasion fit the various theories of invisibility? Journal of Vegetation Science 15: 495-504.

CABI Commonwealth Agricultural Bureau International, 2019, Datasheet: Fallopiasachalinensishttp. (http:// www.cabi.org/isc/datasheet/107744\#8CC9DF2EDD8D-4BC0-9ADA-2C3DDEBF3CEA), [Accessed: 02.08.2019].

Chmura D., Nejfeld P., Borowska M., Woźniak G. \& Tokarska-Guzik B., 2013, The importance of land use type in Fallopia (Reynoutria) japonica invasion in the suburban environment. Pol. J. Ecol. 61 (2): 379-384.

Drzeniecka-Osiadacz A., Kryza M. \& Szymanowski M., 2010, Klimat Wrocławia, [in:] Z. Lewicki (ed.), Środowisko Wrocławia - Informator 2010. Lemitor, Wrocław: 25-38.

Dubicki A., Dębicka M. \& Szymanowski M., 2002, Klimat Wrocławia, [in:] K. Smolnicki, M. Szykasiuk (eds.), Środowisko Wrocławia - Informator 2002. Dolnośląska Fundacja Ekorozwoju, Wrocław: 9-25.

Fabiszewski J. \& Brej T., 2008, Ecological significance of some kenophytes in Lower Silesian national parks. Acta Societatis Botanicorum Poloniae 77: 167-174.

Fojcik B. \& Tokarska-Guzik B., 2000, Reynoutria x bohemica (Polygonaceae) - nowy takson we florze Polski. Fragmenta Floristica et Geobotanica Polonica 7: 63-71.

Francis A.P. \& Currie D.J, 2003, A globally consistent richness-climate relationship for angiosperms. Am Nat 161: 523-536.

Gaertner M., Wilson J. R.U., Cadotte M.W., MacIvor J.S., Zenni R.D. \& Richardson D.D., 2017, Non-native species in urban environments: patterns, processes, impacts and challenges. Biological Invasions 19(12): 3461-3469.

Groeneveld E., Belzile F.J. \& Lavoie C., 2014, Sexual reproduction of Japanese knotweed (Fallopia japonica s.1.) at its northern distribution limit: New evidence of the effect of climate warming on an invasive species. American Journal of Botany 101(3): 1-8.
Kowarik I., 1995a, On the role of alien species in urban flora and vegetation, [in:] P. Pyšek, K. Prach, M. Rejmanek, M. Wade (eds.), Plant Invasions - General Aspects and Special Problems. Academic Publishing, Amsterdam: 85-103.

Kowarik I., 1995b, Time lags in biological invasions with regard to the success and failure of alien species, [in:] P. Pyšek, K. Prach, M. Rejmanek, M. Wade (eds.), Plant Invasions - General Aspects and Special Problems. Academic Publishing, Amsterdam: 15-38.

Kühn I., Wolf J. \& Schneider A., 2017, Is there an urban effect in alien plant invasions? Biological Invasions 19(12): 3505-3513.

Mandák B., Pyšek P. \& Bímová K., 2004, History of the invasion and distribution of Reynoutria taxa in the Czech Republic: a hybrid spreading faster than its parents. Preslia 76(1): 15-64.

Nobis M.P., Jaeger J.A.G. \& Zimmermann N.E., 2009, Neophyte species richness at the landscape scale under urban sprawl and climate warming. Diversity and Distributions 15: 928-939.

Parepal M., Fischer M. \& Bossdor O., 2013, Environmental variability promotes plant invasion. Nature Communications 4, 1604. (https://doi.org/10.1038/ncomms2632).

Pysek P., 1998, Alien and native species in Central European urban floras: a quantitative comparison. Journal of Biogeography 24: 155-163.

Rahmonov O., Czylok A., Orczewska A., Majgier L. \& Parusel T., 2014, Chemical composition of the leaves of Reynoutria japonica Houtt. and soil features in polluted areas. Cent. Eur. J. Biol. 9: 320-330.

Richards Ch. L., Walls R. L., Bailey J.P., Parameswaran R., George T. \& Pigliucci M., 2008, Plasticity in salt tolerance traits allows for invasion of novel habitat by Japanese knotweed s. 1. (Fallopia japonica and F. $\mathrm{x}$ bohemica, Polygonaceae). American Journal of Botany 95: 931-942.

Säumel I. \& Kowarik I., 2010, Urban rivers as dispersal corridors for primarily wind-dispersed invasive tree species. Landscape and Urban Planning 94: 244+249.

Siemens T. \& Blossey B., 2007, Anevaluation of mechanisms preventing growth and survival of two native species in invasive Bohemian Knotweed (Fallopia $\times$ bohemica, Polygonaceae). American Journal of Botany 94: 776-783.

Sołtysiak J. \& Brej T., 2012, Characteristics that make the Fallopia genus (Polygonaceae) highly invasive. Ecological Questions 16: 23-28.

Sołtysiak J. \& Brej T., 2014, Invasion of Fallopia genus plants in urban environment on the example of Wrocław city. Pol. J .Environ. Stud. 23: 449-458.

Sołtysiak J. \& Brej T., 2019, Effect of soil srtificially polluted with lead on an invasive Fallopia x bohemica: 
A case study from Central Europe. Pol. J. Environ. Stud. 28(6): 1-9.

Studnik-Wójcikowska B., 2012, Flora miasta - chaos i przypadek, czy prawidłowości w różnorodności. Kosmos, Problemy Nauk Biologicznych 51(2): 213-219.

Szymanowski M., 2004, Miejska Wyspa Ciepła we Wrocławiu. Wydawnictwo Uniwersytetu Wrocławskiego, Wrocław.

Tokarska-Guzik B., Dajdok Z., Zając M., Zając A., Urbisz A., Danielewicz W. \& Hołdyński Cz., 2012. Rośliny obcego pochodzenia w Polsce ze szczególnym uwzględnieniem gatunków inwazyjnych. Generalna Dyrekcja Ochrony Środowiska, Warszawa.

Tokarska-Guzik B., Fojcik B., Bzdęga K., Urbisz A., Nowak T., Pasierbiński A. \& Dajdok Z., 2015, Wytyczne dotyczące zwalczania rdestowców na terenie Polski. (http://www.gdos.gov.pl/files/artykuly/5050/Wytyczne_dotyczące_zwalczania_rdestowcow_na_terenie Polski.pdf), [Accessed: 02.08.2019].

Yamaguchi, F., Nozue, M., Yasuda, H. and Kubo, H. 2000. Effects of temperature on the pattern of anthocyanin accumulation in seedlings of Polygonum cuspidatum. J. Plant Res. 113: 71-77. 